\title{
STUDY DIARIES IN TRANSLATION EDUCATION AT TALLINN UNIVERSITY
}

\author{
Triin Pappel, Tiia Falk
}

\begin{abstract}
In translator education, different introspection and retrospection methods are used. In this article, we present a retrospection method called study diaries. The goal of study diaries should be to guide translation students towards learning how to find adequate solutions to problems on their own and to make students aware of the different aspects of their action (or the process of translation, etc.), which could then help them be aware of the lifelong learning aspect, as well as of the importance of being able to reflect, analyse, and be self-critical.
\end{abstract}

Keywords: translation, translation education, self-assessment and self-analysis

\section{Introduction}

In recent years, a number of studies on the academic environment have suggested ways of assessing both the product and the process of translation. It is hoped that by making the process of learning transparent, we can better judge and predict the quality of the end product and, therefore, be in better control of the efficiency of training. It has been emphasized in previous research that through feedback and self-assessment learners develop their self-concept and self-confidence, which can be considered as crucial for academic progress and successful careers.

The role of a translator has changed rapidly over recent years - the image of the translator, the ways and methods of the translator's work, have changed dramatically. As described by Daniel Gouadec:

The qualified professional translator is a vital player, both economically and technically: professional translators are highly skilled technical experts, both on account of the contents they translate and of the various ever more sophisticated IT tools and software they must be able to use. Languages are essential, but insufficient. What is needed beyond absolute linguistic proficiency is a perfect knowledge of the relevant cultural, technical, legal, 
commercial backgrounds, and a full understanding of the subject matter involved. (Gouadec 2007: xiii).

Translators may be called upon to translate just about anything. Any text, message, fragment of a message or code element may need to be translated. (Gouadec 2007: 4)

The consequences of these changes are now reflected in one of the main difficulties that has arisen in translator education - preparing students for the constantly changing market. On top of all this, terminological issues in Translation Studies have often proved to be a problem, as has been discussed in various articles (e.g. Marco 2009, Snell-Hornby 2009).

According to Andrew Chesterman, "the general goal of understanding a phenomenon means that we need access to appropriate concepts, to an ability to describe and explain" (Chesterman 2007: 2). One solution in preparing the students for a demanding market is to help students understand that they need to learn how to make decisions and how to be critical as well as self-critical. To achieve this, different methods have been adopted in translation education, one of which is the process-oriented approach. Daniel Gile believes that "the process-oriented approach has a number of advantages over the traditional product-oriented method in the earlier stages of Translation training. The idea is that in the classroom, trainers should focus on the Translation process, not on the end product." Gile (2009: 14). As Gile suggests:

More specifically, rather than giving students texts to translate or speeches to interpret, commenting on the Translation produced by saying what is "right" and what is "wrong", suggesting appropriate solutions and counting on the accumulation of such indications to guide trainees up the learning curve, in the process-oriented approach, trainers attempt to identify problems in the process followed by the students, raise their awareness of problems and suggest good principles, methods and procedures. (Gile 2009: 14)

A research study was carried out at Tallinn Pedagogical University in 2004 "to find out how to facilitate the process through which the translators join the profession" (Sass 2004: 42). The result of this study was the conclusion that: "Translator education is most efficient for all parties in the learning process when self-assessment and feedback are seen as the content as well as the method for organizing learning activities" (Sass 2004: 43).

Following this study and other similar studies, methods of self-assessment, self-analysis and self-criticism have become an important part of the curriculum at Tallinn University, and the students are encouraged constantly to analyse and criticize their own work. One of the aims of using self-assessment methods (study diaries, project work and similar methods) is to help the students to start thinking about the process of translation/interpreting, about their own conceptions of translation by discussing their work and the problems they come across in texts they have translated, and to make them aware of the conceptions of translation, as well as of the role of the translator. 


\section{Method}

In this article, we would like to present ways of implementing study diaries in translator education and hope to offer practical guidelines on what works and what is effective to anyone planning to implement study diaries as a part of translator education.

The overall purpose of the study was to find out:

- Whether using study diaries would help students to start thinking about their own conceptions of translation and to appreciate the connections between practice and theory,

- Whether using study diaries helps students map the essence of a translator's work and role in society,

- Whether working in a team helps students analyse themselves and their work as a translator better,

- Whether using study diaries is a useful learning tool and if it is an adequate means of self-assessment.

In translation studies, different introspection/retrospection methods can be used, e.g., Think Aloud Protocols (TAP) (e.g. Kussmaul, Tirkkonen-Condit 1995), and other retrospection methods are also popular. Daniel Gile has used systematic reporting of problems and decisions encountered by translation students in their translation assignments for 25 years (Gile 2004). In 2004, Gyde Hansen carried out a project at the Copenhagen Business School, called the Copenhagen Retrospection Project. "It is a systematic comparison of several methods for introspection, the Integrated Problem and Decision Report (IPDR) by Gile (2004), Retrospection with Replay with Translog $(\mathrm{R}+\mathrm{Rp})$ and Retrospection with Replay combined with cognitive clarification via an immediate dialogue (ID) between the subject and the observer (R+Rp+ID)" (Hansen 2006: 2).

The aim of Hansen's study was to investigate "Störquellen, which are sources of disturbance in translation processes (SDs), i.e. the sources of translation problems that are either overlooked in translation teaching or that cannot be coped with properly because of lack of time" (Hansen 2006: 2).

In our study, we have used a retrospection method, namely study diaries. The application of this method takes place after the translation process, and although it is sometimes regarded as less reliable than, for example, TAPs (Krings 1986: 68), it is still a widely used method in translation education. The goal of the study diaries is to guide the students towards learning to find adequate solutions to problems on their own, and to make students aware of the different aspects of their action.

\section{Description of the translation project}

Second-year Translation MA students were observed in the translation classroom, while they were working on a project with an authentic text. The students were translating a special report of the Estonian Court of Auditors, and it was later assessed and discussed by Estonian translators working at the Court of Auditors (i.e., by a so-called "real client"). 
The students had to work as a team, and they had to solve the problems they encountered during the project work together as a group. There were 21 students altogether, working in three different groups of 7 students. Every student had his or her own personal task, but the final translation was the result of teamwork. In every group, there was one project manager, two proofreaders who were also responsible for the coherence of the translated text, and four translators.

During the project, the students were also asked to keep a study diary. At the end of the project, after they had received feedback, they were also asked to fill out a questionnaire. In this particular course, the purpose of the study diaries was to make the students reflect on their own activities, to make them aware of the process of translating and also the main factors that influenced their work, e.g. factors influencing decisions made in the translating process (without taking any stand on the suitability of those decisions at this stage), and to find out which steps they had taken to find possible solutions or strategies. After the translation project, when the students had received feedback from the "real client" and the teacher, they were also asked to fill in a questionnaire, to find out whether this exercise helped the students to start thinking about their own conceptions of translation, whether it was useful as a learning tool, and whether it was adequate as a means of self-assessment.

\section{Analysis of the diaries}

The guidelines given to the students were not particularly rigid, because the primary goal was to encourage them to start reflecting upon themselves and not to focus on strict guidelines. There were 21 study diaries in total, all quite different in their approaches, but the students were asked to concentrate on three main issues:

- Factors that might help/disturb/preclude translating;

- Comments and feelings about their work;

- What they learned.

\subsection{Factors that might help/disturb/preclude translating}

The students brought forth very different factors that had helped, disturbed or precluded their work in translating the text. Below are the most common factors the students mentioned:

- Daily routine and work - most students were translating in the evening when they were tired;

- Sometimes they had to translate too many hours in a row;

- In some cases, translating took more time than planned;

- An important factor is the emotional balance, e.g. some days are better than others;

- Students were constantly worried about the deadline (they were scared that there was not enough time to finish the project);

- The students admitted their lack of knowledge in translation technology and in computer skills (formatting the text and the tables was very difficult, time consuming and frustrating); 
- Sometimes there were problems with accessing the internet or the computer was very slow;

- Family problems, e.g. children were ill;

- Factors distracting their attention, e.g. the TV was on, children were restless or partner was interrupting;

- Students had difficulties in finding the adequate terminology or background information (they were not sure how long it takes to find an appropriate solution or where to look to find the adequate terminology, etc);

- Problems in communication with other group members (trusting other group members);

- Some students felt more responsible for the task because it was group work;

- Some students admitted a lack of background knowledge (they had problems understanding the text);

- Some felt a lack of experience;

- Some students were not motivated enough (only interested in getting a good grade);

- They had problems inside the group (some translators were cutting corners, some not keeping to the deadline, proofreaders felt they had to do too much and be responsible more than the translators, the project manager was too arrogant, etc).

\subsection{Main problems and aspects students were concentrating on}

The main problems that occurred during the translation process and self-analyses were the following:

- Students had problems in formatting the text and tables;

- There were many problems with finding the adequate terminology;

- There were many discussions about the semantics and the coherence in the translation;

- Students were also concentrating a lot on trusting each other and on communication problems inside the group;

- One of the main problems they had to concentrate on was the lack of time.

\subsection{Comments and feelings about their work}

The students made different comments and reached conclusions that describe their work:

- Students realized that the more they read their text, the less they saw their own mistakes;

- Students understood that it is useful to discuss everything with the proofreader;

- Students now understood better the problems with coherence in the text and in the terminology;

- An important conclusion was made - the text was easy to understand, but not easy to translate; 
- $\quad$ Time management was essential;

- Students admitted that it was useful to organize such a task in the so-called "safe environment" of the classroom;

- Students also commented when they were not happy or very happy with the final result;

- The most important conclusion that was drawn was the understanding that if it had been a "real translation job", some students would have rejected it because it was too difficult for them.

\subsection{What did the students learn?}

The students also had to comment on what they learned in the process of the translation project and the self-assessment and analyses:

- Discussing the problems and finding adequate solutions together in the group is useful and essential;

- Always trust only yourself;

- The translator has to be responsible for his or her own translation and not rely on the proofreader;

- The proofreader or the project manager should not accept translations where corners have been cut;

- A project manager's job is very difficult;

- Computer skills are essential for translators (although a couple of students denied this need - according to them a translator does not need that kind of skills, because the translator only has to translate).

\section{Analysis of the questionnaire}

After the translation project and after receiving feedback from the "real client", Estonian translators working at the Court of Auditors, the students were asked to fill out a questionnaire. The questionnaire was designed as part of a larger research project and consisted of eighteen open-format questions concerning the issues - besides the described translation project and used study diaries -, of different teaching methods used in the Translation MA programme at Tallinn University, as well as issues concerning theoretical and academic background for practising translators. The first eight questions were about different teaching methods and the aim was to find out which of the listed methods best helped the students prepare themselves for the real translation market. Questions 13 to 15 concerned another retrospection method students had to use in the classroom: reviewing and commenting on their own translations and on the translations of their peers. The aim of questions 16 to 18 was to find out whether the students find an academic and theoretical background essential and useful for a practising translator.

For the purposes of this article, only three questions were pertinent (questions 10 to 12 , see Table 1 ). There were 21 students in the project and 21 students answered the questionnaire. Because the research method we used was qualitative and not quantitative, figures in the table and the analysis below are merely illustrative, providing a better overview of the overall results. 
Table 1. Illustrative results of the questionnaire (questions 10 to 12)

\begin{tabular}{|c|c|c|c|}
\hline Answers & $\begin{array}{c}\text { Question 10: } \\
\text { Did analysing your own work } \\
\text { (in the form of the study } \\
\text { diary) help you start thinking } \\
\text { about your own conceptions } \\
\text { of translation and realize } \\
\text { the connections between } \\
\text { practice and theory? }\end{array}$ & $\begin{array}{l}\text { Question 11: } \\
\text { Did analysing your } \\
\text { own work (in the } \\
\text { form of the study } \\
\text { diary) help map } \\
\text { the essence of a } \\
\text { translator's work } \\
\text { and role in society? }\end{array}$ & $\begin{array}{l}\text { Question 12: } \\
\text { Did analysing your } \\
\text { own translation } \\
\text { and your peers' } \\
\text { translation help you } \\
\text { analyse yourself } \\
\text { and your work as a } \\
\text { translator better? }\end{array}$ \\
\hline Yes, it did & 9 & 6 & 17 \\
\hline $\begin{array}{l}\text { It did help to some } \\
\text { degree }\end{array}$ & 4 & 4 & 2 \\
\hline It did help only a little & 1 & 5 & - \\
\hline It did not help & 6 & 5 & 1 \\
\hline Difficult to say & 1 & 1 & - \\
\hline $\begin{array}{l}\text { The question was not } \\
\text { answered }\end{array}$ & - & - & 1 \\
\hline
\end{tabular}

As the table shows, most of the students (9 out of 21) found using the study diaries useful (Question 10), because it made them start thinking about their own conceptions of translation and also see better the links between practice and theory in translation. Four students said it was helpful to some degree, one said it did help only a little, six didn't find it helpful at all and one was not sure.

Those who found it helpful said, for example, that it is always very useful to analyse your own work. The idea of putting down their own thoughts helped them analyse every little detail better and that helped them to start thinking about what translation and translating is.

Those who found it helpful to some degree said, for example, that the process of self-analysing is constantly happening anyway, and using study diaries for that is probably a good exercise for beginners but not necessarily for an experienced translator.

Of those who didn't find it helpful at all, some offered no further explanation, but those who made a comment indicated that they didn't believe in this kind of method, because according to them it was time-consuming and distracting.

Answers to Question 11 (Did analysing your own work (in the form of the studydiary) help map the essence of a translator's work and role in the society?) were more diverse. Only six students out of 21 found it to be very useful; according to four students it was useful to some degree, and five found it only slightly useful. Five students didn't find the study diary useful at all in this context and one was not sure.

Those students who found using study diaries helpful didn't comment on their answers. Those who found it helpful to some extent or a little mostly said that it was useful, but what was most useful was the project work itself, not the analysis. Here students unfortunately failed to see the link between the actual translating and commenting on their work in the diaries.

For Question 12 (Did analysing your own translation and your peers' translation help you analyse yourself and your work as a translator better?), the most popular action was still working in a team, being able to correct and analyse their peers' 
translations and proofreading. Seventeen students out of 21 found it very useful, two students found it useful to some degree, only one didn't find it useful at all and one chose not to answer this question.

According to those who found the exercise helpful: it helped them realize what their own strengths and weaknesses are; it was interesting to see the solutions of their peers; it helped to them start reading their own work with some distance; it made them realize that practice makes perfect; and they also found that there is still a lot they don't know. Those students who didn't find the exercise to be helpful commented that only real practice is important and not the analysis itself.

\section{Conclusions}

Altogether, we could still say that the majority of the Translation students considered using study diaries as a method for self-assessment and self-analysis to be a useful and helpful tool. Many students did admit the importance of this kind of exercise in the Translation classroom, and many students started to realize the importance of self-analysis through the study diaries. They also started to think about the conceptions of translation, the essence of a translator's work and the role of the translator in society.

Further study on use of the diaries will consider feedback from students who have already used them, from which it can be deduced that instructions for what to record perhaps need to be more explicit. There is definitely potential here for further studies, with a larger set of data and the final results of the students who have completed the two-year programme.

\section{References}

Chesterman, Andrew 2007. On the idea of a theory. - Across Languages and Cultures, 8 (1), 1-16. http://dx.doi.org/10.1556/Acr.8.2007.1.1

Gile, Daniel 2004. Integrated problem and decision reporting as a translator training tool. Journal of Specialised Translation, 2, 2-20.

Gile, Daniel 2009. Basic Concepts and Models for Interpreter and Translator Training. Revised Edition. Amsterdam, Philadelphia: John Benjamins Publishing Company.

Gouadec, Daniel 2007. Translation as Profession. Amsterdam, Philadelphia: John Benjamins Publishing Company.

Hansen, Gyde 2006. Retrospection methods in translator training and translation research. Journal of Specialised Translation, 5, 2-41.

Krings, Hans-Peter 1986. Was in den Köpfen von Übersetzern vorgeht. Tübingen: Narr.

Kussmaul, Paul; Tirkkonen-Condit, Sonja 1995. Think-aloud protocol analysis in translation studies. - TTR: traduction, terminologie, rédaction. Association canadienne de traductologie, 8 (1), 177-199.

Marco, Josep 2009. The terminology of translation. - Yves Gambier, Luc van Doorslaer (Eds.). The Metalanguage of Translation. Amsterdam, Philadelphia: John Benjamins Publishing Company, 65-81.

Pinazo, Encarnación Postigo 2008. Self-assessment in teaching interpreting. - TTR: traduction, terminologie, rédaction. Association canadienne de traductologie, 21 (1), 173-209.

Sass, Eve 2004. Enesehindamine ja tagasiside tõlkijakoolituse tulemuslikkuse tagamisel. Magistritöö. Tallinna Pedagoogikaülikool: Tallinn. 
Snell-Hornby, Mary 2009. What's in a name? On metalinguistic confusion in Translation Studies. - Yves Gambier, Luc van Doorslaer (Eds.). The Metalanguage of Translation. Amsterdam, Philadelphia: John Benjamins Publishing Company, 123-135.

Triin Pappel (Tallinn University) teaches translation. Her research interests include: written translation, translation education, translation process.

tpappel@tlu.ee

Tiia Falk (Tallinn University) teaches conference interpreting and is a freelance conference interpreter and translator. Her research interests include: simultaneous and consecutive interpreting, interpreter/ translator training methods, practical training tools.

tiiafalk@tlu.ee 


\section{TÕLKEPÄEVIKUd TÕLKIJAKOOLITUSES}

\section{Triin Pappel, Tiia Falk}

Tallinna Ülikool

Tõlkepäevikuid kasutatakse õppevahendina palju. Päevikute peamine eesmärk on aidata tudengitel analüüsida seda, kuidas nad õpivad ja miks nad õpivad. Kirjaliku tõlke õpetamisel on tõlkepäevikud samuti üsna levinud õppevahendiks ja siin on nende üheks kõige olulisemaks eesmärgiks see, et tudengid õpiksid eneseanalüüsi kaudu leidma adekvaatseid lahendusi töös ette tulevatele tõlkeprobleemidele: Samuti on oluline, et tulevased tõlkijad õpiksid teadvustama oma tegevust tõlkijana ehk tõlkimise protsessi.

Tallinna Ülikoolis on tõlkepäevikuid kasutatud kirjaliku tõlke magistriõppes suuremate tõlkeprojektide juures eneseanalüüsi ja enesehindamise vahendina.

Antud uurimuse ja artikli eesmärk oli saada teada:

- $\quad$ kas tõlkepäevikute kasutamine aitab kaasa sellele, et tudengid hakkaksid mõtlema ja arutlema tõlke olemuse üle ning näeksid seost teooria ja praktilise tegevuse vahel;

- $\quad$ kas tõlkepäevikute kasutamine aitab tudengitel kaardistada tõlkija töö olemust ning tõlkija sotsiaalset rolli;

- kas projektitöö, ehk töö rühmas, aitab kaasa sellele, et tudengid õpiksid paremini analüüsima ennast ja oma tööd tõlkijana.

Tõlkepäevikute ja läbiviidud küsitluse analüüsi tulemusena võib öelda, et suurem osa kirjaliku tõlke tudengeid pidas tõlkepäevikut heaks eneseanalüüsi vahendiks, paljude meelest aitas see neil teadvustada eneseanalüüsi vajalikkust, pani nad mõtlema tõlke olemuse ja tõlkija sotsiaalse rolli üle.

Võtmesõnad: tõlkimine, tõlkijaharidus, eneseanalüüs 